\title{
APLIKASI MATRIKS QUALITY FUNCTION DEPLOYMENT (QFD) PADA PERANCANGAN ULANG MEJA BELAJAR MINI
}

\author{
Diana Khairani Sofyan ${ }^{* 1}$, Amri' \\ ${ }^{1,2}$ Jurusan Teknik Industri, Fakultas Teknik, Universitas Malikussaleh, Lhokseumawe \\ e-mail: ${ }^{* 1}$ hatikue@yahoo.com
}

\begin{abstract}
CV. Rapi Kana is a furniture company in Ule Reuleng North Aceh, the company produces cabinets, study chairs, tables, study tables and more. The chair and lecture desk is one of the most closely related factors in improving the quality of student learning. Discomfort in learning to make students less focused and tend to get tired quickly in doing tasks and lecture activities. The main cause lies on the desk used. The lesson used is less suitable for the student body size. Dissociation between study desk and student body size is one of the obstacles in the effort to improve the quality human resources. The impact of desks that are not in accordance with body size can lead to many students experiencing fatigue. Nonconformity of the desk leads to feelings of discomfort (restlessness), lack of concentration, drowsiness, and so forth. In this case will be done research related to the design of the mini desk, where the study table produced by the company will be analyzed its shortcomings and advantages, followed by redesign for the desk. The design is adapted to the posture of the human body. The method used to start with the determination of product characteristics with Quality Function Deployment (QFD) method and also from the calculation of antropometry data so that the result of mini table design in accordance with consumer desire that is comfortable, effective and efficient.
\end{abstract}

Keywords: Quality Function Deployment (QFD) method, Anthropomentry, Mini table design

\section{PENDAHULUAN}

\subsection{Latar Belakang}

CV. Rapi Kana merupakan perusahaan mebel yang berada di Ule Reuleng jalan Medan-Banda Aceh, Aceh Utara, perusahaan ini setiap bulannya memproduksi berupa lemari, kursi belajar, meja, meja belajar dan lain-lain. Kursi dan meja kuliah merupakan salah satu faktor yang paling berhubungan erat dalam meningkatkan kualitas belajar mahasiswa. Apabila meja belajar yang dipakai tidak ergonomis, maka pada saat dilaksanakannya proses belajar mahasiswa tidak dapat fokus terhadap kegiatan belajar yang sedang berlangsung, karena kursi kuliah yang sedang dipakai belum terasa nyaman.

Meja belajar yang digunakan sekarang, oleh beberapa mahasiswa terbuat dari bahan triplek dan kayu. Kenyataan yang terlihat bahwa untuk postur tubuh mahasiswa sekarang tampak lebih kecil dibandingkan dengan anak terdahulu. Dampak dari ketidakserasian antara meja belajar dengan ukuran tubuh mahasiswa merupakan salah satu kendala dalam upaya meningkatkan sumber daya manusia yang berkualitas. Akibat dari meja belajar yang tidak sesuai dengan ukuran tubuh antara lain dapat mengakibatkan para 
mahasiswa banyak mengalami kelelahan. Ketidaksesuaian meja belajar mahasiswa dengan ukuran tubuh mahasiswa dapat pula menimbulkan perasaan tidak nyaman (gelisah), kurang konsentrasi, mengantuk, dan lain sebagainya. Apabila kondisi tersebut berlangsung lama (selama masa proses belajar), akibat lebih jauh akan menyebabkan perubahan sikap tubuh

dan gangguan pertumbuhan. Secara keseluruhan akibatnya akan mengarah kepada gangguan dalam proses belajar.

Maka dari itu perusahaan harus bisa merancang meja belajar mini sesuai dengan postur tubuh manusia, sehingga tidak mudah merasa lelah pada saat duduk yang lama. Sebelumnya perusahaan membuat produk meja belajar tanpa mengukur dimensi tubuh pelajar atau mahasiswa sehingga sering terjadinya keluhan pada mahasiswa. Namun dari berbagai tipe dan variasi produk meja belajar mini yang dipasarkan, ternyata belum sepenuhnya memberi fungsi seperti apa yang diharapkan oleh konsumen sasaran. Konsumen membeli meja belajar mini tersebut karena memang suatu kebutuhan, tetapi dalam penggunaanya masih ada aspek-aspek yang dikeluhkan konsumen. Hal yang dapat dilakukan pada penelitian ini adalah melakukan rancangan meja belajar mini dengan pengaplikasian Matriks Quality Function Deployment (QFD), dimana tahapan awal akan dilakukan analisis atribut dan penilaian pada perancangan meja belajar mini yang nantinya akan diperoleh hubungan yang sangat mempengaruhi model rancangan meja belajar yang diinginkan konsumen. Berdasarkan hal tersebut maka dilakukan penelitian mengenai "Aplikasi Matriks Quality Function Deployment (QFD) Pada Perancangan Ulang Meja Belajar Mini”.

\subsection{Masalah penelitian}

1. Permasalahan yang diteliti adalah permasalahan yang berkaitan dengan Bagaimana mengetahui karakteristik meja belajar yang sesuai kebutuhan dan keinginan konsumen melalui metode Quality Function Deployment (QFD).

2. Bagaimana merancang meja belajar yang efektif dan efisien dengan menggunakan antropometri sehingga dapat memenuhi kriteria kebutuhan yang diharapkan konsumen.

\subsection{Tujuan yang ingin dicapai}

Adapun tujuan yang ingin dicapai pada penelitian ini adalah sebagai berikut:

1. Mengetahui karakteristik meja belajar mini yang sesuai kebutuhan dan keinginan konsumen melalui metode Quality Function Deployment (QFD).

2. Mendesain sebuah meja belajar mini yang efektif dan efisien yang mampu memenuhi kriteria kebutuhan berdasarkan data anthropometri yang diharapkan konsumen sasaran.

\subsection{Penerapan hasil kegiatan}

Adapun penerapan hasil kegiatan adalah perusahaan dapat mendesain sebuah meja belajar mini sesuai dengan karakteristik yang sesuai dengan keinginan konsumen yang disesuaikan dengan data antropometri, sehingga diperoleh meja belajar mini yang efektif dan efisien.

\section{TINJAUAN PUSTAKA}

\subsection{Pengertian Perancangan}

Perancangan suatu proses yang bertujuan untuk menganalisis, menilai memperbaiki dan menyusun suatu sistem, baik sistem fisik maupun non fisik yang 
optimum untuk waktu yang akan datang dengan memanfaatkan informasi yang ada. Perancangan suatu alat termasuk dalam metode teknik, dengan demikian langkah-langkah perancangan akan mengikuti metode teknik. Merris Asimov menerangkan bahwa perancangan teknik adalah suatu aktivitas dengan maksud tertentu menuju kearah tujuan dari pemenuhan kebutuhan manusia, terutama yang dapat diterima oleh faktor teknologi peradaban kita. Dari definisi tersebut terdapat tiga hal yang harus diperhatikan dalam perancangan yaitu [1]:

1. Aktivitas dengan maksud tertentu

2. Sasaran pada pemenuhan kebutuhan manusia dan

3. Berdasarkan pada pertimbangan teknologi

Tahapan perancangan sistem kerja menyangkut work space design dengan memperlihatkan faktor anthropometri secara umum adalah [2]:

1. Menentukan kebutuhan perancangan dan kebutuhan (establish requirement).

2. Mendefinisikan dan mendeskripsikan populasi pemakai.

3. Pemilihan sampel yang akan diambil datanya

4. Penentuan kebutuhan data (dimensi tubuh yang akan diambil).

5. Penentuan sumber data (dimensi tubuh yang akan diambil) dan pemilihan persentil yang akan dipakai.

6. Penyiapan alat ukur yang akan dipakai.

7. Pengambilan data.

8. Pengolahan data.

9. Visualisasi rancangan.

\subsection{Pengertian Produk}

Produk dapat didefinisikan sebagai segala sesuatu yang dapat ditawarkan produsen untuk diperhatikan, diminta, dicari, dibeli, digunakan atau dikonsumsi pelanggan sebagai pemenuhan kebutuhan dan keinginan pelanggan [3]. Terdapat tiga komponen utama yang membentuk suatu produk antara lain:

1. Komponen pembungkus. Atribut utama yang dimiliki produk dalam mengkomunikasikan dan membawa manfaat bagi produk tersebut. Atribut ini antara lain kualitas rancangan, kemasan dan merek

2. Komponen inti. Manfaat utama dari produk tersebut yang benar-benar dicari pelanggan atau karena alasan pelanggan mencari produk tersebut.

3. Komponen pendukung. Manfaat dan jasa tambahan yang diperoleh pelanggan dari produk tersebut seperti garansi, jaminan, perawatan dan pengiriman.

Produk adalah segala sesuatu yang dapat ditawarkan ke pasar untuk mendapatkan perhatian, untuk dimiliki, digunakan, atau dikonsumsi dan dapat memuaskan kebutuhan dan keinginan konsumen. Barang atau jasa tidak hanya berarti karakteristik fisik saja, tetapi terdiri dari komponen inti, komponen pembungkus, dan komponen pendukung [4].

\subsection{Atribut Produk}

Atribut adalah "unsur-unsur produk yang dipandang penting oleh konsumen dan dijadikan dasar pengambilan keputusan pembelian". Atribut produk secara umum meliputi [5]:

a. Desain Produk

Indriyo Gito Sumarno menyatakan bahwa "desain atau bentuk produk merupakan atribut yang sangat penting untuk mempengaruhi konsumen agar mereka tertarik dan kemudian membelinya". 
b. Warna produk

Penglihatan merupakan indera yang utama bagi manusia dalam mengeksploitasi dan memahami dunia. Warna merupakan elemen penting dalam desain grafis yang memiliki pengaruh besar terhadap penglihatan. Pada suatu produk, warna adalah elemen penting yang dilihat pertama kali oleh audiens. Warna juga merupakan hal yang menjadi pertimbangan kualitas suatu produk.

c. Merek

Merek adalah "nama, istilah, simbol, atau rancangan, atau kombinasi dari hal-hal tersebut yang dimaksudkan untuk mengidentifikasi barang atau jasa dari seseorang atau sekelompok penjual dan untuk membedakannya dengan pesaing-pesaing".

d. Kemasan

Pengemasan (packaging) adalah "kegiatan-kegiatan umum dalam perencanaan barang yang melibatkan penentuan desain dan pembuatan bungkus atau kemasan bagi suatu barang, "pengemasan, berkaitan dengan perancangan dan pembuatan wadah atau pembungkus untuk suatu produk".

\subsection{Pembuatan Kuisioner}

Kuisioner merupakan sejumlah pertanyaan tertulis yang digunakan untuk memperoleh informasi dari responden dalam arti tentang laporan pribadinya, atau hal-hal yang ia ketahui. Tujuan pokok pembuatan kuisioner adalah untuk memperoleh informasi yang relevan dengan tujuan survei dengan cara mengisi pertanyaan yang diajukan peneliti terhadap responden yang dipilih. Ada empat komponen inti dari sebuah kuisioner, yaitu [6]:

1. Adanya subjek, yaitu individu atau lembaga yang melaksanakan penelitian.

2. Adanya ajakan, yaitu permohonan dari peneliti untuk turut serta mengisi secara aktif dan objektif pertanyaan maupun pertanyaan yang tersedia.

3. Adanya petunjuk pengisian kuisioner, dimana petunjuk yang tersedia harus mudah dimengerti.

4. Adanya pertanyaan maupun pernyataan beserta tempat mengisi jawaban, baik secara tertutup, semi tertutup, ataupun terbuka. Dalam membuat pertanyaan ini juga disertakan dengan isian untuk identitas responden.

\subsection{Matrik Quality Fuction Deployment (QFD)}

QFD merupakan sebuah metode perencanaan dan pengembangan produk terstruktur yang memungkinkan team pengembangan untuk menentukan secara jelas kebutuhan dan keinginan konsumen dan kemudian mengevaluasi kapasitas setiap proposal dan produk dan jasa secara sistematis [2]. Proses didalam QFD dilaksanakan dengan menyusun satu atau lebih matrik yang disebut House Of Quality. Matrik ini menjelaskan apa yang menjadi kebutuhan dan harapan pelanggan dan bagaimana memenuhinya. Matrik ini terdorong dari beberapa bagian atau submatrik yang bergabung dalam beberapa cara, yang disebut House Of Quality. Matriks dengan House Of Quality (HOQ) ini terdiri dari beberapa bagian atau sub matriks yang bergabung dalam beberapa cara yang dapat dilihat pada Gambar 1. 


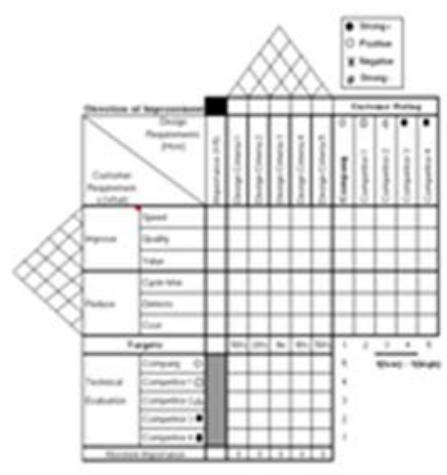

Gambar 1. House of Quality [6]

Tahap-tahap implementasi Quality Function Deployment (QFD) secara umum yaitu [6]: 1. Fase pengumpulan secara konsumen (Voice Of Customer)

Prosedur umum dalam pengumpulan suara konsumen adalah :

a. Menentukan atribut-atribut yang dipentingkan konsumen (berupa data kualitatif). Dan data ini biasanya diperoleh dari wawancara dan observasi terhadap konsumen.

b. Mengukur tingkat kepentingan dari atribut-atribut, dengan tahapan berikut.

1) Untuk mengukur derajat kepentingan dari tiap atribut dapat digunakan rumus sebagai berikut:

$\bar{X}=\frac{\sum_{i=1}^{n} D K I}{n}$

Dimana

DKI $=$ Derajat kepentingan responden ke-i

$\mathrm{n} \quad=$ Jumlah Responden

2) Untuk menghitung kinerja atribut produk dapat menggunakan rumus:

$\bar{X}=\frac{\sum_{i=1}^{n} K I}{n}$

Dimana:

$\mathrm{Ki}=$ Kepuasan responden ke- $\mathrm{i}$

$\mathrm{n}=$ Jumlah responden

3) Menentukan nilai target dari setiap atribut produk

4) Untuk menentukan rasio perbaikan

Rasio Perbaikan $=\frac{\text { Nilai } \text { Target }}{\text { Kinerja Jasa }}$

5) Identifikasi parameter teknik (technical requirement)

6) Menentukan interaksi antara keinginan pelanggan dengan parameter teknik.

7) Nilai matrik interaksi keinginan pelanggan dengan parameter teknik dapat digunakan rumus :

$\mathrm{Kti}=\mathrm{Bti} \mathrm{Hi}$

Dimana :

$\mathrm{KTi}=$ Nilai absolute kebutuhan teknik setiap produk

Bti $=$ Kepentingan relatif (bobot) keinginan pelanggan yang memiliki hubungan dengan atribut produk. 
$\mathrm{Hi}=$ Nilai hubungan keinginan pelanggan yang memiliki hubungan dengan atribut produk.

8) Prioritas kebutuhan teknik berdasarkan kepentingan relative adapun rumusnya dapat digunaka sebagai berikut

Kepentingan Relatif $=\frac{\text { Kebutuhan Teknik Absolut }}{\sum \text { Kebutuhan Teknik Absolut }} \times 100 \%$

2. Fase penyusunan rumah kualitas (House Of Quality)

Langkah-langkah dalam penulisan rumah kualitas meliputi [7]:

a. Pembuatan matrik kebutuhan konsumen, tahap ini meliputi:

1) Menentukan konsumen

2) Mengumpulkan data keinginan dan kebutuhan konsumen.

b. Pembuatan matrik perencanaan, tahap ini meliputi:

1) Mengukur kebutuhan konsumen

2) Menentukan kebutuhan performansi komsumen.

a) Pembuatan Respon Teknis

b) Tahap ini merupakan tahap pemunculan karakteristik kualitas pengganti (Subtitute Quality Characteristic). Pada tahap ini dilakukan transformasi dari kebutuhan yang berisi non teknis menjadi data yang bersifat teknis guna memenuhi kebutuhan-kebutuhan konsumen.

c) Menentukan Hubungan Respon Teknis dengan Kebutuhan Konsumen

d) Tahap ini menentukan seberapa kuat hubungan antara respon teknis dengan kebutuhan konsumen. Hubungan antara keduanya bisa berupa hubungan yang sangat kuat, sedang dan lemah. Dan ini merupakan bagian dari HOQ yang menghubungkan antara ruang hows dan whats. Matriks ini mengaitkan hubungan respon teknis/ technical requirement dengan voice customer.

e) Korelasi Teknis

f) Tahap ini menggambarkan hubungan dan ketergantungan antar respon teknis. Sehingga dapat dilihat apakah suatu respon teknis yang satu mempengaruhi respon teknik yang lain.

g) Benchmarking dan Penetapan Target.

h) Tahap ini dilakukan analisa perbandingan bagi pesaing dengan perusahaan. Sehingga dapat diketahui tingkat persaingan yang terjadi.

i) Fase Analisa dan Interprestasi

j) Merupakan analisa dari tahap-tahap tersebut.

\subsection{Anthropometri}

Pengertian Anthropometri adalah berasal dari kata "anthro" yang berarti manusia dan "metri" yang berarti ukuran. Secara definitif dapat dinyatakan sebagai satu studi yang berkaitan dengan pengukuran dimensi tubuh manusia. Manusia pada dasarnya akan memiliki bentuk, ukuran (tinggi, lebar, dsb) berat dan lain-lain yang berbeda satu dengan yang lainnya. Untuk memperjelas mengenai data anthropometri untuk diaplikasikan dalam berbagai rancangan produk ataupun fasilitas kerja. Pada Gambar 2 akan memberikan informasi tentang berbagai macam dimensi tubuh yang perlu diukur [8]. 


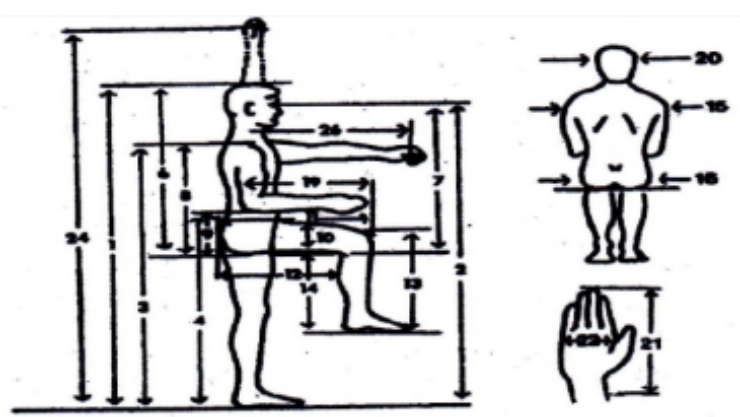

Gambar 2. Anthropometri Dimensi Tubuh Manusia [7]

Keterangan :

1. Dimensi tinggi tubuh posisi berdiri (dari lantai sampai dengan ujung kepala)

2. Tinggi mata dalam posisi berdiri tegak

3. Tinggi bahu dalam posisi berdiri tegak

4. Tinggi siku dalam posisi berdiri tegak

5. Tinggi kepalan tangan yang terlanjur lepas dalam posisi berdiri tegak (dalam gambar diatas tidak ditampakkan)

6. Tinggi badan dalam posisi duduk (diukur dari alas tempat duduk / pantat sampai dengan kepala)

7. Tinggi mata dalam posisi duduk

8. Tinggi bahu dalam posisi duduk

9. Tinggi siku dalam posisi duduk

10. Tebal atau lebar paha

11. Panjang paha diukur dari pantat sampai ujung lutut/ betis

12. Panjang paha diukur dari pantat sampai bagian belakang dari lutut atau betis

13. Tinggi lutut yang bisa diukur baik dalam posisi berdiri maupun duduk

14. Tinggi tubuh dalam posisi duduk yang diukur dari lantai sampai paha

15. Lebar dari bahu (bias diukur dalam posisi berdiri atau duduk)

16. Lebar pinggul atau pantat

17. Lebar dari dada dalam keadaan membusung (tidak tampak ditunjukkan dalam gambar)

18. Lebar perut

19. Panjang siku yang diukur dari siku sampai dengan ujung jari-jari dalam posisi siku tegak lurus

20. Lebar kepala

21. Panjang tangan diukur dari atas pergelangan sampai ujung jari

22. Lebar tangan

23. Lebar telapak tangan sampai ibu jari (tidak ditunjukkan dalam gambar)

24. Tinggi jangkauan tangan dalam posisi berdiri tegak, diukur dari lantai sampai dengan telapak tangan yang terjangkau lurus keatas (vertical)

25. Tinggi jangkauan tangan dalam posisi berdiri tegak, diukur seperti halnya no. 24 dalam posisi duduk (tidak ditunjukkan dalam gambar)

26. Jarak jangkauan tangan yang terlanjur kedepan diukur dari bahu sampai ujung jari tangan

Data anthropometri dibuat sesuai dengan ukuran tubuh laki-laki dan perempuan. 


\section{METODE PENELITIAN}

Metode penelitian yang digunakan pada penelitian ini Model yang digunakan Metode QFD dimana analisis persoalan dan tahapan rancangan dilakukan dengan metode QFD (Quality Function Deployment).

Tahapan rancangan penelitian, yaitu:

a. Melakukan perhitungan jumlah sample yang diperlukan.

b. Menetukan karakteristik produk sesuai dengan keinginan konsumen.

c. Menggambarakan matriks QFD.

d. Menentukan data yang berkaitan dengan data antropomentri.

e. Melakukan perhitungan persentil.

f. Analisis hasil perhitungan.

Untuk memperoleh hasil penelitian, maka data yang telah dikumpulkan kemudian diolah melalui pendekatan matriks QFD yang digunakan adalah analisis QFD berantai, artinya analisis matrik house of quality (HOQ) menggunakan lebih dari satu matrik HOQ. Analisis QFD memperbolehkan lebih dari satu matrik HOQ dengan tujuan agar output dari QFD lebih teknis dan spesifik. Pada penelitian ini menggunakan satu saja matriks HOQ. Analisis Matriks HOQ (House Of Quality).

\section{HASIL DAN PEMBAHASAN}

\subsection{Pengumpulan Data}

A. Data Sampel Penelitian

Dalam penelitian ini populasinya adalah mahasiswa teknik industri dari angkatan tahun 2010 sampai tahun 2017 yaitu sebesar 490 orang. Dari hasil perhitungan jumlah sampel yang digunakan adalah 98 dan di genapkan menjadi 100 responden yang diambil dari mahasiswa sebagai pengguna atau pembeli produk meja belajar mini.

B. Analisa Karakteristik

Mengidentifikasi keinginan konsumen ke dalam atribut-atribut produk. Untuk mengetahui keinginan konsumen terhadap meja belajar mini, maka dalam pengumpulan data dilakukan dengan penyebaran kuisioner kepada 98 sampel orang. Penyebaran kuisioner ini dilakukan melalui 2 tahap yaitu kuisioner terbuka dan tertutup. Data atribut meja belajar mini yang diinginkan oleh konsumen pada Tabel 1 berikut.

Tabel 1 Data atribut meja belajar mini yang diinginkan oleh konsumen

\begin{tabular}{|c|c|c|c|c|}
\hline \multirow{2}{*}{ No } & \multicolumn{4}{|c|}{ Atribut } \\
\hline & Primer & & Sekunder & Tersier \\
\hline \multirow{3}{*}{1} & \multirow{3}{*}{ Fungsional } & $\mathrm{a}$ & Ketinggian meja & $26,4 \mathrm{Cm}$ \\
\hline & & & Memiliki ruang/tempat & Laptop \\
\hline & & b & penyimpanan & Alat tulis \\
\hline \multirow{6}{*}{2} & \multirow{6}{*}{ Desain } & & & Hemat tempat \\
\hline & & $\mathrm{c}$ & Ukuran meja & Panjang $82,4 \mathrm{Cm}$ \\
\hline & & & & Lebar $60 \mathrm{Cm}$ \\
\hline & & $\mathrm{d}$ & Kaki meja & Mampu menahan keseimbangan \\
\hline & & $\mathrm{e}$ & Bentuk meja & Persegi \\
\hline & & $\mathrm{f}$ & Permukaan meja & Luas \\
\hline 3 & Bahan & $\mathrm{g}$ & Kekuatan bahan & Tahan lama \\
\hline
\end{tabular}


Tidak mudah patah

\begin{tabular}{|c|c|c|c|c|}
\hline & & h & Ringan & Mudah dipindah-pindahkan \\
\hline 4 & Estetika & 1 & Warna meja & Bervariasi \\
\hline 5 & Harga & $\mathrm{k}$ & Ekonomis & Terngkau \\
\hline
\end{tabular}

\subsection{Pengolahan Data}

Perhitungan QFD yang digunakan adalah analisis QFD berantai, artinya analisis matrik house of quality (HOQ) menggunakan lebih dari satu matrik HOQ. Analisis QFD memperbolehkan lebih dari satu matrik HOQ dengan tujuan agar output dari QFD lebih teknis dan spesifik. Pada penelitian ini menggunakan satu saja matriks HOQ.. Analisis Matriks HOQ (House Of Quality) adapun tahap-tahapa membuat Matriks HOQ (House Of Quality) ialah sebagai berikut :

1. Menghitung derajat kepentingan relatif butir atribut produk

Derajat kepentingan digunakan untuk memposisikan setiap keinginan ataupun kebutuhan pelanggan dalam bentuk data kuantitatif dengan tujuan untuk memprioritaskan keinginan konsumen. Pemberian bobot dimulai dari atribut yang sangat penting dengan nilai 5 sampai pada atribut yang tidak penting dengan nilai 1 yang diberikan oleh setiap responden dapat dihitung dengan pada persamaan 1, sehingga:

$$
\bar{X}=\frac{\sum_{i=1}^{n} D K I}{n}=\frac{334}{100}=3.34
$$

Perhitungan secara keseluruhan dari derajat kepentingan relatif butir atribut produk meja belajar dapat dilihat pada Tabel 2 .

Tabel 2. Derajat kepentingan relatif atribut produk sendiri

\begin{tabular}{clc}
\hline No & \multicolumn{1}{c}{ Pertanyaan } & $\begin{array}{c}\text { Derajat } \\
\text { Kepentingan }\end{array}$ \\
\hline 1 & Ketinggian Meja dapat disesuaikan & 3,34 \\
2 & Memiliki ruang/tempat dalam penyimpanan leptop dan & 3,78 \\
& alat tulis & \\
3 & Ukuran Meja tidak terlalu besar (hemat tempat) & 3,56 \\
4 & Bentuk kaki meja mampu menahan keseimbangan & 3,66 \\
5 & Bentuk meja mudah dibersihkan & 3,66 \\
6 & Permukaaan meja luas & 3,82 \\
7 & Kekuatan bahan tahan lama dan tidak mudah patah & 3,26 \\
8 & Ringan mudah dipindah-pindahkan & 3,68 \\
9 & Kekuatan meja mampu menahan beban & 3,36 \\
10 & Warna meja bervariasi & 3,62 \\
11 & Harga bersaing dengan produk lain (standar) & 3,84 \\
\hline
\end{tabular}

Menghitung nilai atribut produk pesaing

2. Kinerja atribut produk meja belajat dipandang dari sisi konsumen adalah untuk menentukan besarnya nilai target oleh pihak perusahaan. Atribut produk yang dianggap sangat tidak baik pelayanannya diberi nilai 1 dan atribut produk yang sangat baik pelayanannya diberi nilai 5 . Kinerja atribut produk dihitung dengan rumus sesuai persamaan 1. Hasil perhitungan diperoleh Permukaaan meja luas, memiliki ruang/tempat dalam penyimpanan leptop dan alat tulis dan harga bersaing dengan produk lain (standar). 
Menentukan nilai target

3. Nilai target ditentukan oleh pihak responden. Penetapan nilai target harus sesuai dengan kelebihan dan kelemahan dengan mempertimbangkan kondisi internal dan eksternal.

4. Menentukan rasio perbaikan

Rasio perbaikan bertujuan mengetahui nilai yang harus dicapai oleh pemakai produk meja belajar untuk mencapai nilai target yang ditetapkan

5. Menentukan Sales Point

Sales Point memberik informasi tentang kemampuan sebuah perusahaan dalam menjual produk yang didasarkan pada seberapa jauh kebutuhan pelanggan dapat dipenuhi. Nilai yang digunakan dalam sales point yaitu tidak terdapat penjualan (1), titik penjualan tengah atau sedang $(1,2)$ dan titik penjualan tinggi $(1,5)$.

Menentukan nilai bobot atribut produk meja belajar

6. Atribut kepuasan produk yang akan ditingkatkan dan dikembangkan perlu ditentukan bobot prioritas terlebih dahulu.

Menentukan nilai normalisasi bobot

7. Bobot dari masing-masing atribut yang telah dihitung perlu dinormalisasi. Hal ini untuk memudahkan dalam perhitungan selanjutnya. Hasil perhitungan keseluruhan dari normalisasi bobot dapat dilihat pada Tabel 3.

Tabel 3 Normalisasi bobot atribut kepuasan produk

\begin{tabular}{clcc}
\hline No & \multicolumn{1}{c}{ Atribut Kepuasan Produk } & Bobot & $\begin{array}{c}\text { Normalisasi } \\
\text { Bobot }\end{array}$ \\
\hline 1 & Ketinggian Meja dapat disesuaikan & 7,411 & 0,103 \\
2 & Memiliki ruang/tempat dalam penyimpanan leptop & 7,620 & 0,106 \\
& dan alat tulis & 7,716 & 0,108 \\
3 & Ukuran Meja tidak terlalu besar (hemat tempat) & 6,032 & 0,084 \\
4 & Bentuk kaki meja mampu menahan keseimbangan & 5,982 & 0,084 \\
5 & Bentuk meja mudah dibersihkan & 7,660 & 0,107 \\
6 & Permukaaan meja luas & 4,711 & 0,066 \\
7 & Kekuatan bahan tahan lama dan tidak mudah patah & 7,751 & 0,108 \\
8 & Ringan mudah dipindah-pindahkan & 5,662 & 0,079 \\
9 & Kekuatan meja mampu menahan beban & 4,865 & 0,068 \\
10 & Warna meja bervariasi & 6,260 & 0,087 \\
11 & Harga bersaing dengan produk lain (standar) & & \\
\hline
\end{tabular}

8. Mengidentifikasi hubungan antara atribut produk dengan karakteristik teknik Matrik antara atribut produk meja belajar mini dan karakteistik teknik dapat dilihat pada Gambar 3.

9. Mengidentifikasi hubungan antara sesama karakteristik teknik bertujuan untuk mengidentifikasi hubungan antara sesama karakteristik yang satu dengan yang lainnya. Nilainya dapat bernilai hubungan positif kuat (4), hubungan positif sedang (3), hubungan negatif sedang (2) dan hubungan negatif kuat (1).

Kesimpulan dari gambar QFD adalah:

1. Atribut meja belajar mini dari hasil kuisioner adalah:

a. Meja belajar mini yang memiliki kaki penyangga yang dapat mengatur ketinggian meja.

b. Meja belajar mini yang memiliki memiliki laci penyimpanan laptop dan alat tulis. 
c. Meja belajar mini yang memiliki ukuran tidak terlalu besar sehingga hemat tempat.

d. Meja belajar mini yang memiliki desain kaki penyangga efektif sehingga mampu menahan keseimbangan.

e. Meja belajar mini yang memiliki bentuk sederhana sehingga mudah saat dibersihkan.

f. Meja belajar mini yang memiliki permukaan yang luas.

g. Meja belajar mini yang terbuat dari bahan yang tahan lama dan tidak mudah patah.

h. Meja belajar mini yang memiliki komposisi bahan ringan sehingga mudah dipindah-pindahkan.

i. Meja belajar mini yang memiliki rakitan yang kuat sehingga mampu menahan beban.

j. Meja belajar mini yang memiliki desain menarik.

k. Meja belajar mini yang memiliki warna bervariasi

1. Meja belajar mini yang memiliki harga standar

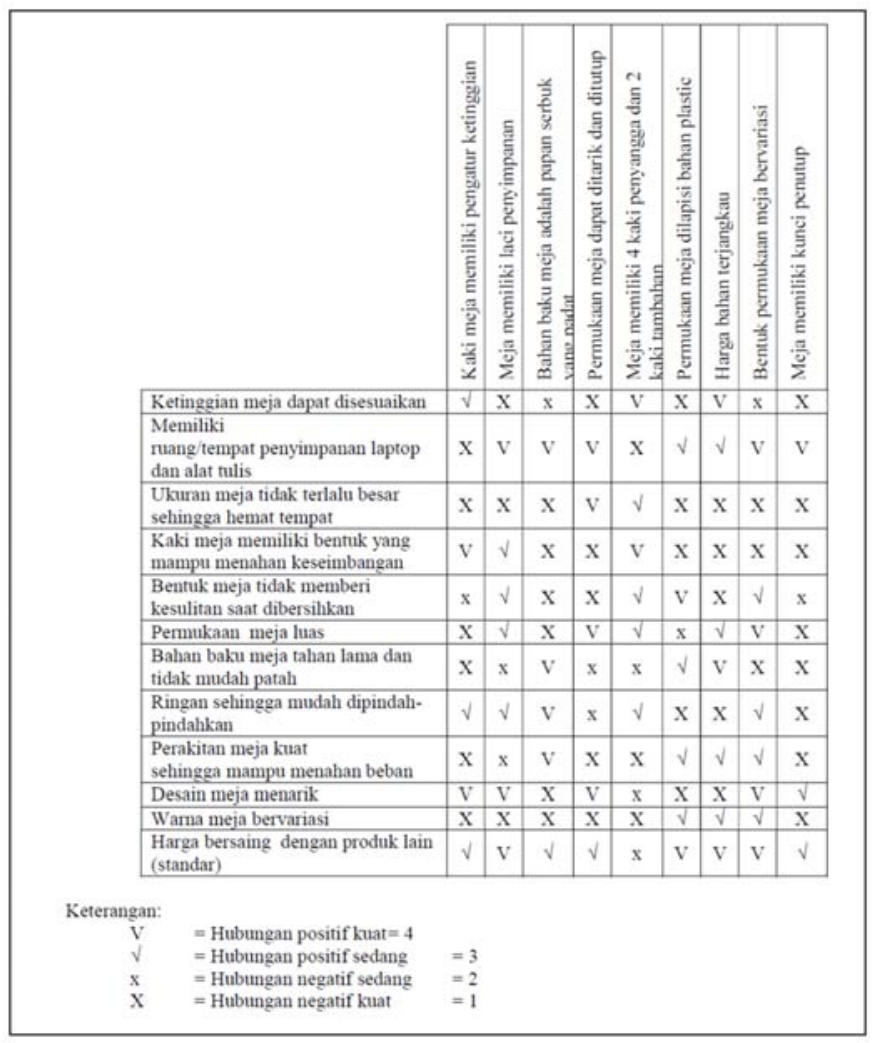

Gambar 3. Matrik antara atribut produk meja belajar mini dan karakteistik teknik.

2. Perbandingan meja belajar mini hasil penyebaran kuisioner dengan produk dari pesaing pada atribut yang sama adalah :

a. Untuk kaki penyangga, desain produk lebih unggul dari produk pesaing.

b. Untuk laci penyimpanan, desain produk lebih unggul dari produk pesaing.

c. Untuk ukuran meja produk yang di desain juga lebih unggul dari produk pesaing.

d. Untuk desain kaki penyangga yang efektif, produk lebih unggul dari produk pesaing. 
e. Untuk kemudahan perawatan dari bentuk meja, produk yang didesain oleh perusahaan seimbang dengan produk pesaing.

f. Untuk luas permukaan meja, produk lebih unggul dari produk pesaing.

g. Untuk bahan/material yang digunakan, produk yang didesain seimbang dengan produk pesaing.

h. Untuk tingkat keringanan bahan meja, produk lebih unggul dari produk pesaing.

i. Untuk kekuatan perakitan, produk yang di desain juga lebih unggul dari produk pesaing.

j. Untuk desain yang menarik, produk yang didesain oleh seimbang dengan produk pesaing.

k. Untuk variasi warna, produk yang didesain seimbang dengan produk pesaing.

1. Untuk standar harga, desain produk lebih unggul dari produk pesaing.

3. Tingkat kesulitan: Semua krakteristik teknik tersebut termasuk ke dalam kategori pekerjaan yang mudah untuk dikerjakan.

4. Tingkat kepentingan: Karakteristik teknik yang tergolong cukup penting yaitu Kaki meja memiliki ditarik dan ditutup, Meja memiliki 4 kaki penyangga, Permukaan meja dilapisi bahan plastic. Harga bahan terjangkau, Meja memiliki kunci penutup, sedangkan untuk karakteristik yang tergolong penting yaitu meja memiliki laci penyimpanan dan bentuk permukaan meja bervariasi.

Perkiraan biaya dari produk rancangan meja belajar mini untuk seluruh karakteristik teknik tergolong dalam kategori murah.

\subsection{Racangan Produk awal dan Rancangan produk usulan}

Berikut rancangan awal (produk yang telah ada) dan rancangan produk usulan yang dapat dilihat pada Gambar 4 dan 5.

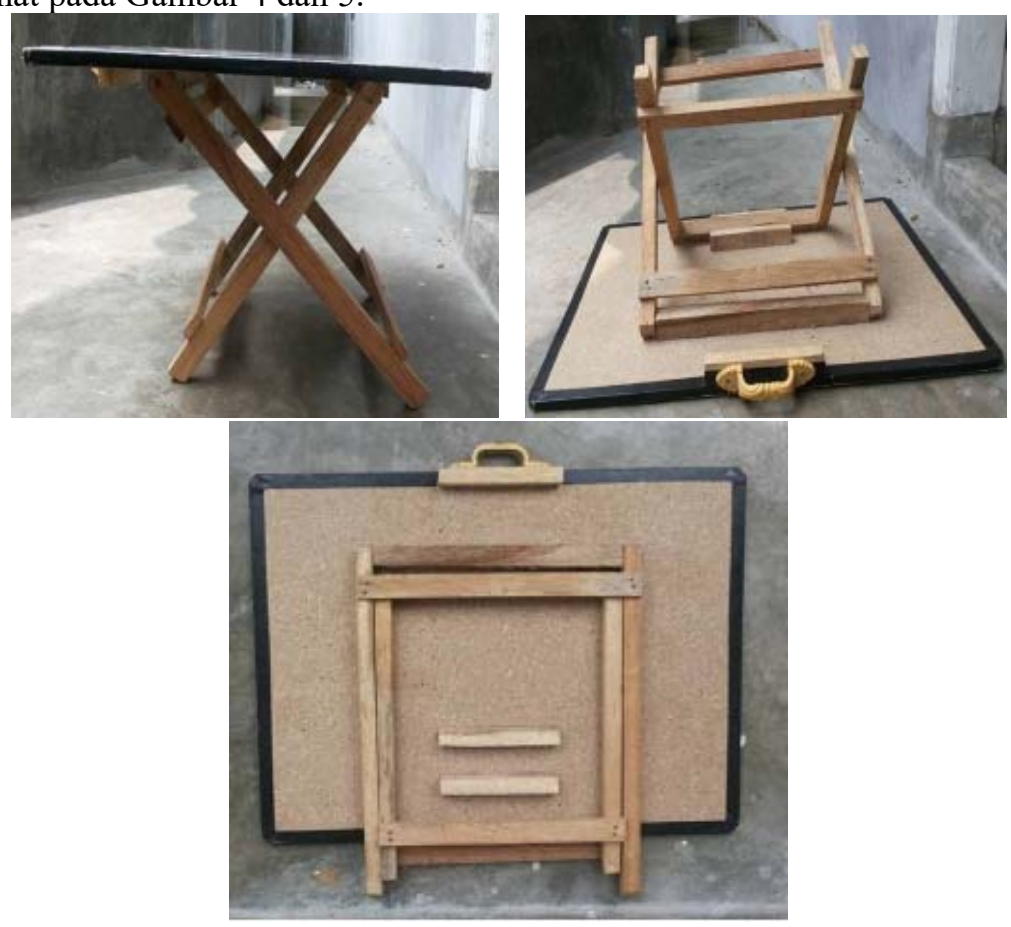

Gambar 4 Meja belajar mini rancangan awal 


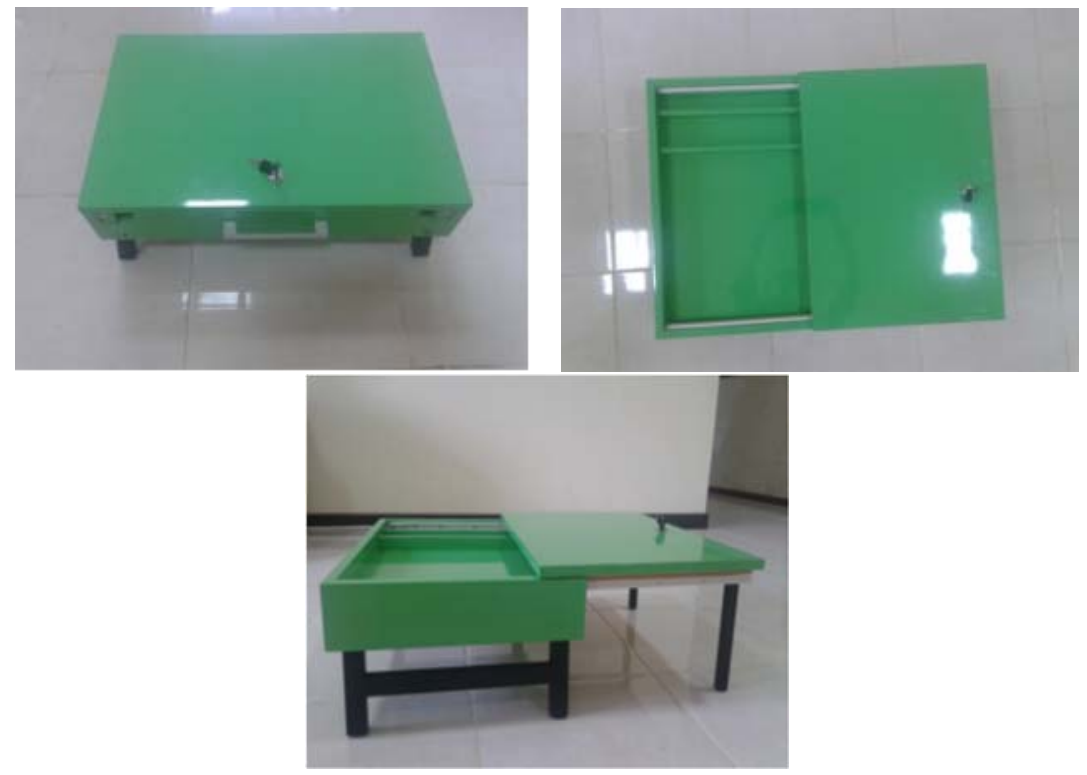

Gambar 5. Rancangan meja belajar mini usulan.

\section{KESIMPULAN}

Adapun kesimpulan dari penelitian adalah sebagai berikut:

1. Karakteristik meja belajar mini yang sesuai keinginan konsumen berdasarkan kuisioner yang disebarkan adalah harga bersaing dengan produk lain (standar), permukaan meja luas, dan memiliki ruang/tempat dalam penyimpanan laptop dan alat tulis . Sedangkan atribut paling penting dianggap konsumen adalah ringan mudah dipindahkan yaitu bernilai $0,105 \%$.

2. Perancangan meja belajar mini yang efektif dan efisien dengan menggunakan anthropometri berdasarkan dimensi tubuh manusia yang dibutuhkan adalah dengan nilai persentil 95 th $(1,645)$ diantaranya yaitu: $26,46 \mathrm{~cm}$ yaitu tinggi meja dari lantai, $82,42 \mathrm{~cm}$ lebar meja secara keseluruhan pada saat laci buka, $12,33 \mathrm{~cm}$ gagang pegangan tangan pada laci, dan $16,33 \mathrm{~cm}$ ialah tinggi penyangga pada kaki tambahan.

\section{DAFTAR PUSTAKA}

[1] Eko Nurmianto. 2004. Ergonomi Konsep Dasar dan Aplikasi, Edisi ke-2. Surabaya: Guna Widya.

[2] Cohen, 2008. Quality Function Deployment: How to Make QFD Work for You. Addison Wasley Publishing Company. Massachussete.

[3] Parasuraman, 2011. Metode Penelitian Bisnis, Cetakan Ketujuh: Alfabeta, Bandung

[4] Hisrich dan Peters, 2011. Quality Function Deployment, linking a company with its customers. ASQC Quality Press, Milwaukee, Wisconsin 
[5] Wignjosoebroto, S., 2003. Ergonomi, Studi Gerak dan Waktu. Jakarta: Guna Widya.

[6] Ginting Rosnani, 2010. Perancangan Produk. Yogyakarta: Graha Ilmu.

[7] Tarwaka, dkk, 2004. Ergonomi Untuk Keselamatan, Kesehatan Kerja dan Produktifitas. Surakarta: Penerbit Uniba Press.

[8] Karl T. Ullrich dan Steven D. Eppinger. 2001. Perancangan dan Pengembangan Produk. Edisi pertama. Salemba Teknika, Jakarta 